\title{
Financial Liberalization, Bank Crises and Growth: Assessing the Links*
}

\author{
${\text { Alessandra Bonfiglioli }{ }^{\dagger} \text { and Caterina Mendicino }}^{\ddagger}$ \\ SSE/EFI Working Paper Series in Economics and Finance \\ No 567 \\ October, 2004
}

\begin{abstract}
This paper studies the effects of financial liberalization and banking crises on growth. It shows that financial liberalization spurs on average economic growth. Banking crises are harmful for growth, but to a lesser extent in countries with open financial systems and good institutions. The positive effect of financial liberalization is robust to different definitions. While the removal of capital account restrictions is effective by increasing financial depth, equity market liberalization affects growth directly. The empirical analysis is performed through GMM dynamic panel data estimations on a panel of 90 countries observed in the period 1975-1999.

JEL classification: C23, F02, G15, O11.

Keywords: Capital account liberalization, equity market liberalization, financial development, institutions, dynamic panel data.
\end{abstract}

\footnotetext{
${ }^{*}$ We are indebted to Martin Floden, Lars Ljungqvist, Torsten Persson, Fabrizio Zilibotti for helpful discussions, to Axel Dreher and participants at IIES Macro Workshop, EEA Meeting 2003 and SSE Seminar for their comments. We also thank Gian Maria Milesi Ferretti for providing data on capital account liberalization. We are grateful to Annika Andreasson for editorial assistance. Financial support from the Jan Wallander Foundation (J02/37) is gratefully aknowledged. This paper was partly written while Mendicino visited the George Washington University and the Universita' Roma Tre, whose hospitality she gratefully acknowledges. All eventual errors are ours. Comments are welcome.

${ }^{\dagger}$ IIES, Stockholm University. E-mail: alessandra.bonfiglioli@iies.su.se

${ }^{\ddagger}$ Stockholm School of Economics. E-mail: Caterina.Mendicino@hhs.se
} 


\section{Introduction}

In the last two decades an increasing number of countries have eliminated controls on international capital movements. However, the global economic crises of recent years have led many economists to reconsider the beneficial effects of financial liberalization on economic performance. Although the issue has been widely debated, there are no conclusive results on the effects of financial integration on growth ${ }^{1}$.

In theory, international financial liberalization softens financing constraints and improves risk-sharing, thereby fostering investments. It may also have a positive impact on the functioning and development of financial systems, and on corporate governance ${ }^{2}$. These arguments suggest that we should expect a positive relation between international financial liberalization and economic growth ${ }^{3}$. However, the presence of distortions may reduce the positive effects of liberalization. In fact, information asymmetries may lead to a bad allocation of capital, and weak financial and legal systems could induce capital flights towards countries with better institutions. Moreover, banking crises may come along with financial liberalization, as it is well documented in the literature ${ }^{4}$.

Table 1 shows mean equality tests for growth, financial development and the occurrence of banking crises across different treatment (open, bank crises) and control (closed, no crises) groups of countries, observed annually between 1975 and 1999. The results suggest that countries without restrictions on capital account or equity market transactions had, on average, higher growth rates and financial development (as measured by credit to the private sector as a ratio of GDP). The occurrence of banking crises is associated with lower growth rates and financial development. However, it is not clear whether there is correlation between openness and the occurrence of bank crises. When we consider an overall index there is no significant difference in the frequency of crises between countries with and without restrictions on capital account transactions. The picture becomes clearer once we split the index between "systemic" and "non-systemic" banking crises.

\footnotetext{
${ }^{1}$ See Edison et al. (2003) for a review of the empirical literature.

${ }^{2}$ See Klein and Olivei (2000) and Levine (2000) for empirical evidence on the positive impact of financial liberalization on growth, .

${ }^{3}$ Evidence on the positive relation between financial development and growth is provided by a large literature (see Demirguc-Kunt and Levine, 2001 for a survey). The results in La Porta et al. (1999) suggest that good corporate governance spurs growth.

${ }^{4}$ See Kaminsky and Reinhart (1999) and Aizenmann (2002) for a survey.
} 
Open countries experienced a lower number of systemic crises but a higher number of non-systemic crises. The higher frequency of non-systemic crises may be a reason for the concern of economists and governments on the effects of financial liberalization on economic performance.

In this paper we assess empirically the effects of international financial liberalization and banking crises on growth. We admit the possibility that banking crises come along with financial liberalization, as shown by previous works and by row 5 of Table 1, and investigate their joint impact on growth ${ }^{5}$. Kaminsky and Schmukler (2002) and Tornell et al. (2004) suggest in different ways that institutional quality may matter at shaping the relationship between financial liberalization, crises and long-run growth ${ }^{6}$. Therefore, we control for institutions and their interactions with financial openness and crises. To have a better understanding of the mechanism that links the variables of our interest, we assess whether liberalization and crises affect growth through financial depth. Also in this case, we control for institutional quality. Inspired by the results in Acemoglu and Johnson $(2003)^{7}$, we distinguish between institutions aimed at contractual as opposed to property rights protection.

The empirical analysis is performed on a panel dataset that covers 90 countries over the period 1975-1999. We adopt the Dynamic Panel Data approach proposed by Arellano and Bover (1995) and Blundell and Bond (1998). We use two indicators of financial liberalization, that distinguish between capital account and equity market liberalization.

Our results show that capital account liberalization has a positive effect on growth, once we control for banking crises, whose impact is negative. The absence of capital account controls is good for growth because it fosters financial development and mitigates the harmful effects of banking crises. Capital account liberalization allows firms to raise funds more easily on the

\footnotetext{
${ }^{5}$ Causality between financial liberalization and banking crises is left aside from our empirical analysis.

${ }^{6}$ Kaminsky and Schmukler (2002) show evidence that equity market liberalization brings about financial chaos in the short-run, but has positive long-run effects, since it induces changes in institutions supporting the functioning of the domestic financial market. Tornell et al. (2004) suggest that liberalization and crises affect growth through financial development; given financial openness, good institutions make bank crises less likely, and foster capital inflows.

${ }^{7}$ Acemoglu and Johnson (2003) show that contractual protection affects financial structure more than property rights protection, but has limited effects on economic performance. Vice versa, property right protection affects GDP growth, productivity and investments, but not the financial structure.
} 
international financial markets, and thus suffer less from domestic crises. Moreover, banking crises turn out to be less harmful for growth in countries where property and contractual rights are better protected. Equity market liberalization instead has a strong direct effect on growth and does not interact with banking crises.

There are many contributions in the literature on the effects of financial liberalization on long-run growth. Bekaert, Harvey and Lundblad (2003) is the closest work to this paper. These authors as well consider both capital account and equity market liberalization, and control for bank crises. They also allow for heterogeneity in the effects of liberalization depending on cross-country differences in institutional quality. The main elements that distinguish our contribution are the attention to the interaction between financial liberalization and bank crises, the analysis of the mechanism that links them to growth through financial development and the use of a different dynamic panel data technique.

The remainder of the paper is organized as follows. Section 2 describes the econometric model and the variables we used. Section 3 reports the estimation results and comments on them. Section 4 councludes.

\section{Data and empirical strategies}

\subsection{The econometric model}

We assess the growth effects of financial liberalization and banking crises by adding these variables to a dynamic version of the standard growth regression ${ }^{8}$. We follow the dynamic panel data approach suggested by Arellano and Bover (1995) and Bond and Blundell $(1998)^{9}$. This methodology is preferred to the cross-sectional regressions because it allows to account for the impact of the policy changes, imbedded in the indexes of financial liberalization and of crisis episodes, on growth. This dynamic panel technique is also helpful to amend the bias induced by omitted variables in cross-sectional estimates, and the inconsistency caused by endogeneity both in cross-sectional and static panel (fixed and random effects) regressions.

We formulate the standard neoclassical growth model in a dynamic panel

\footnotetext{
${ }^{8}$ See among others, Barro (1997) and Barro and Sala-i-Martin(1995).

${ }^{9}$ The system-DPD methodology dominates the difference-DPD proposed by Arellano and Bond (1991) because it amends problems of measurement error bias and weak instruments, arising from the persistence of the regressors (as pointed out by Bond et al., 2001).
} 
data form, and estimate the following dynamic system:

$$
\begin{aligned}
\Delta y_{i t} & =\alpha \Delta y_{i t-1}+\beta^{\prime} \Delta \mathbf{X}_{i t}+\delta \Delta F l i b_{i t}+\gamma \Delta B c r_{i t}+\Delta \nu_{t}+\Delta \epsilon_{i, t} \\
y_{i t} & =\alpha y_{i t-1}+\beta^{\prime} \mathbf{X}_{i t}+\delta F_{l i b}+\gamma B c r_{i t}+\eta_{i}+\nu_{t}+\epsilon_{i, t}
\end{aligned}
$$

where time indexes refer to non-overlapping five-year periods. $\Delta y_{i t}$ is the average annual growth rate of real per capita GDP over five years. $y_{i t}$ is the logaritm of real per capita GDP, and the coefficient on its lag, $\alpha=e^{5 \lambda}$, supports conditional convergence if it implies $\lambda<0$. Variables indexed by $t-1$ are observed at the beginning of the five-year period, and covariates are expressed in period averages. Matrix $\mathbf{X}_{i t}$ contains determinants of GDP growth, such as human capital, population growth and other factors that account for different long-run per capita output across countries. Flib $b_{i(t+k, t)}$ and $B c r_{i(t+k, t)}$ are indicators of financial liberalization and banking crises. $\eta_{i}, \nu_{t}$ and $\epsilon_{i t}$ are respectively the unobservable country- and time-specific effects, and the error term. The presence of country effect in equation (2) corrects the omitted variable bias. The differences in equation (1) and the instrumental variables estimation of the system are aimed at amending inconsistency problems ${ }^{10}$. We instrument differences of the endogenous and predetermined variables with lagged levels in equation (1) and levels with differenced variables in equation (2). For instance, we take $y_{i t-3}$ as instrument for $\Delta y_{i t-1}$ and $F_{l i b} i t-2$ for $\Delta F l i b_{i t}$ in (1) and $\Delta y_{i t-2}$ as instrument for $y_{i t-1}$ and $\Delta F l i b_{i t-1}$ for $F_{i b} b_{i t}$ in (2). We estimate the system by Generalized Method of Moments with moment conditions $E\left[\Delta y_{i t-s}\left(\epsilon_{i t}-\epsilon_{i t-1}\right)\right]=$ 0 for $s \geq 2$, and $E\left[\Delta z_{i t-s}\left(\epsilon_{i t}-\epsilon_{i t-1}\right)\right]=0$ for $s \geq 2$ on the predetermined variables $z$, for equation (1); $E\left[\Delta y_{i, t-s}\left(\eta_{i}+\varepsilon_{i, t}\right)\right]=0$ and $E\left[\Delta z_{i, t-s}\right.$ $\left.\left(\eta_{i}+\varepsilon_{i, t}\right)\right]=0$ for $s=1$ for equation (2). We treat all regressors as predetermined. The validity of the instruments is guaranteed under the hypothesis that $\epsilon_{i t}$ are not second order serially correlated. Coefficient estimates are consistent and efficient if both the moment conditions and the no-serial correlation are satisfied. We can validate the estimated model through a Sargan test of overidentifying restrictions, and a test of second-order serial correlation of the residuals. As pointed out by Arellano and Bond (1991), the estimates from the first step are more efficient, while the test statistics from the second step are more robust. Therefore, we will report coefficients and statistics from the first and second step respectively.

\footnotetext{
${ }^{10}$ See Temple (1999) for a survey on the methodologies used in growth regressions.
} 


\subsection{Financial liberalization and financial fragility: the data}

To explore the impact of financial liberalization and banking crises on growth we need to measure these variables. The literature on financial liberalization has proposed different indicators that differ along several directions. The major distinctions are based on the de iure vs de facto definition criterion, the characterization on a zero-one vs continuous scale, and the market they refer to.

In our analysis we construct an index of liberalization of both capital account and equity market based on two different sources ${ }^{11}$. The first one is a dummy variable provided by the IMF in its Annual Report on Exchange Arrangements and Exchange Restrictions (AREAER), that is available for a maximum of 212 countries starting from $1967^{12}$. This is the most commonly used measure of restrictions on international financial transactions. It takes value 1 if a country has experienced restrictions on capital account transactions during the year, and zero otherwise. Our yearly measure of financial liberalization, opIMF, equals 1 and 0 when the IMF dummy is respectively 0 and 1. The second indicator is based on Bekaert et al.'s (2003) chronology of official equity market liberalization, that is available for 95 countries from 1980. Our variable opBHL differs from opIMF because it only accounts for equity market liberalization, but not for globalization of the credit market for instance. Moreover, differently from the AREAER, Bekaert et al.'s measure does not contemplate policy reversals, so that a country is labeled as open ever since its first year of liberalization. As the IMF-based indicators, it takes value 1 and zero in case of internationally open and closed country-years, respectively. Both opIMF and opBHL are expressed as five-year averages, thereby taking values in the $[0,1]$ interval.

There are alternative measures that are able to account for different degrees of liberalization instead of just the presence or absence thereof. Quinn's (1997) index scores the intensity of capital account controls on a scale from 0 to 4 with steps of 0.5 . However, it is hardly suited for panel studies since it is available for a significant number of countries only for four years, 1958, 1973, 1982 and 1988. Other contributions have used de facto measures, as

\footnotetext{
${ }^{11}$ We focus on de iure zero-one measures, that classify a country as financially liberalized if there are no legal restrictions to international trade of financial instruments.

${ }^{12}$ Classification methods have changed in 1996 , so that there are 13 separate indexes now, that can hardly be compared to the previous single indicator. Miniane (2000) harmonized the classifications, though for a limited number of countries, and over a short time span. Therefore, the last observation for opIMF in our dataset dates back to 1996 .
} 
data on international capital flows as a ratio of GDP. The idea is that actual international capital flows are a good proxy for the degree of financial openness. A more comprehensive discussion on the available indicators can be found in Edison et al. (2002).

Banking crises are subject to various classifications as well. As for liberalization, we adopt a zero-one anecdotal indicator of bank crises, proposed by Caprio and Klingebiel (2001). The authors keep record of 117 systemic and 51 non-systemic crises occurred in 93 and 45 countries respectively, from the late Seventies on. On a yearly base, our variable $B c r$ takes value 2 if the country has experienced a systemic banking crisis, meaning that much or all of a bank's capital has been exhausted; 1 if the banking crisis involved less severe losses; and 0 otherwise. We use two alternative data reductions for robustness analysis: $B c r 012$ takes value 2 if $B c r$ equals 2 at least once over the period, 1 if at least a 1 is scored, zero otherwise. Bcr012av instead accounts also for the duration of crisis episodes, since it equals the period average of $\mathrm{Bcr}$.

The other covariates in our growth regressions are variables commonly accounted for in the empirical growth literature (see Barro, 1997), such as secondary school attainment, the growth rate of population, government expenditure and investments as a ratio of GDP. Other factors that we want to take into account are financial development, proxied by the ratio of credit to the private sector over GDP, and, at a further stage of the analysis, institutional quality, as measured by the government anti-diversion policy index (Hall and Jones, 1999) and by the indicator of efficiency of the judiciary system (see La Porta et al. 2003). The first indicator mainly accounts for property rights protection, while the other refers more to contractual rights.

The sample consists of data for a maximum of 90 countries over the period 1975-1999 or 1980-1999 depending on the indicator of financial liberalization adopted. Since keeping the larger sample gives us a longer timeseries in the panel analysis, we will go on reporting results from the 1975-99 sample for $o p I M F$ and from 1980-99 for opBHL. Since we average over non-overlapping five-year periods, either four or five observations for each country are available. More detail on the countries in our sample and on all variables is given in the appendix. 


\section{Empirical evidence}

\subsection{Liberalization, banking crises and growth}

Table 2 reports results from dynamic-panel estimations of the augmented growth regression, which includes the usual control variables (initial GDP, secondary school attainment, population growth, government spending and investments over GDP) plus indicators of financial liberalization, financial development, and banking crises. Consistently with the previous crosscountry growth studies (see Barro, 1997 and Barro and Sala-i-Martin, 1995), we find significant evidence that countries with lower initial real per capita GDP have grown faster than the initially richer ones, conditional on the other variables. Our estimates imply a convergence rate of about $1.5 \%$ per year ${ }^{13}$. Population growth and investments have the signs predicted by growth theory (respectively negative and positive) in most of the estimates, though not always significant.

Capital account openness has zero-effect on growth. Equity market liberalization instead exhibits a significant positive coefficient (columns 1 and 5). These results are in line with Bekeart et al.'s (2003) findings. Using the same measure of financial liberalization, they show that equity market liberalization significantly affects growth, while the relation between the IMF measure and growth is fragile.

As a wide strand of literature (see Aizenmann, 2002 for a survey) points out, the removal of restrictions on capital flows may expose financial systems to turmoil and possibly crises ${ }^{14}$. If that is the case, the costly impact of financial crises ${ }^{15}$, brought about by liberalization, could be responsible for the coefficient estimates for opIMF in column 1. To control for this hypothesis, we include the bank crisis indicator in the regression of columns 2. Once we control for the occurrence of bank crises, the positive coefficient for opI $M F$ becomes significant. As expected, banking crises strongly restrain growth. Moreover, the interaction between capital account openness and crises in column 3 is positive. This suggests that, irrespective of whether

\footnotetext{
${ }^{13}$ The convergence rate is computed as $\hat{\lambda}=\frac{\ln (\hat{\alpha})}{5}$.

${ }^{14}$ Among others, Kaminsky and Reinhart (1999) show that financial liberalization often precedes banking crises, Glick and Hutchison (1999) find that financially liberalized emerging market economies are more likely to experience twin crises, Demirguc-Kund and Detragiache (1998) show that banking crises occur more often in liberalized financial systems.

${ }^{15} \mathrm{~A}$ number of papers try to quantify the output costs of financial crises. See among others Edwards (1999), Honohan and Klingebiel (2001), and De Gregorio and Lee (2004).
} 
financial liberalization triggers instability in the banking sector, countries without capital account restrictions are less prone to the negative effects of banking crises than financially closed economies. Thus, capital account liberalization has no strong direct effects on growth, but it is important to mitigate the negative effects of banking crises.

The results are slightly different if we restrict the focus on equity market liberalization. As in Bekeart et al., equity market openness and banking crises have indeed strong opposite effects, respectively positive and negative, but the introduction of the crises variable does not affect the effectiveness of equity market liberalization on growth. Moreover, we find no interaction between the two variables (see column 7). In fact, it is not so surprising that free international equity trade alone can be less of help in case domestic banks get into troubles. Firms that rely on credit may be severely hurt by banking crises, and find it difficult to shift abruptly to equity financing, even if they can sell shares on the international market. If instead they have free access to international credit markets, they might raise funds more easily there, and thus suffer less from domestic crises.

Opposite results are obtained by Eichengreen and Leblang (2002). They show that the negative effects of domestic crises are neutralized by the presence of controls on capital controls. One reason could be that they use a different indicator of crises (by Bordo et al., 2001) that encompasses both exchange and banking crises.

As a robustness check, we replicate the estimations in Table 2 using an indicator of Banking crises that accounts also for the duration of banking crises, Bcr012av. Table 5 reports coefficients only for liberalization, bank crises and their interaction. The results are not remarkably different from the ones we obtained using the discrete crisis indicator.

\subsection{Institutions, Financial Liberalization and Growth}

After Hall and Jones' (1999) seminal paper, a wide strand of growth literature has focused on institutions as a primary determinant of economic performance. Alfaro et al. (2004) have shown that institutions are an important determinant of capital inflows. Tornell et al. (2004), in line with this argument, suggest that in financially open countries institutional quality affects both the occurrence of banking crises and the extent of capital inflows. Banking crises may occur as a by-product of openness, as credit markets get thicker, especially if there is a poor legal environment. In open 
economies, the presence of good institutions facilitates capital inflows from abroad, when domestic banking crises reduce the amount of credit available to firms ${ }^{16}$. As a result, banking crises are expected to be less harmful for growth in countries where property and contractual rights are better protected. Symmetrically, financial liberalization might turn out to be growthrestraining in countries with worse institutions. In order to assess empirically these implication we include interactive terms in our dynamic growth regressions.

Table 3 shows results from system-GMM estimations that include the same regressors in columns 1-3 of Table 2, plus the interactions of capital account liberalization with indicators of institutional quality. We also investigate the relation between liberalization, financial development and overall economic development ${ }^{17}$. Institutional quality is proxied here by the government antidiversion policy index constructed by Hall and Jones (1999). This measure varies between $[0,1]$ and takes higher values for governments with more effective policies for supporting production ${ }^{18}$.

Growth is positively affected by financial liberalization and negatively by bank crises under every specification of the model. As reported in column 4, the effect of bank crises is indeed different across countries with good and bad institutions. The term that controls for bank crises in institutionally developed countries is strongly positive. Thus, the cost of banking crises in terms of growth is reduced by good institutions. The interaction with capital account openness, in column 3, is negligible.

As the interaction with credit market development in Column 1 shows, financial liberalization restrains economic growth in countries with small credit markets. Thus, studying the effects of capital account openness on financial development might be of help in understanding the transmission to economic growth. Column 2 shows that banking crises have a bigger impact in countries with high levels of credit market development. In fact, if firms rely more heavily on credit financing, they are more severely hurt by banking crises.

Table $3 \mathrm{~b}$ replicates the exercise of Table 3 using the equity market liber-

\footnotetext{
${ }^{16}$ In Tornell et al. this mechanism works to a different extent across tradables and nontradables sectors. We leave this aspect aside of the analysis.

${ }^{17}$ Financial development is measured by credit market depth, while the index of overall economic development is taken from the classification in World Development Indicators.

${ }^{18}$ The index is an equal-weighetd avarage of 5 variables: (i) law and order (ii) bureaucratic quality (iii) corruption (iv) risk of expropriation (v)government repudiation of contracts.
} 
alization index. The most significant result, in column 5 , points in the same direction as column 5 in Table 3 . Good institutions reduce the destructive effects of bank crises.

Hall and Jones' (1999) indicator of institutional quality accounts mainly for property right protection, i.e. the degree of private property protections against government and elite expropriations. Inspired by Acemoglu and Johnson (2003), we assess the role of institutions aimed at protecting private contracts. Thus, we replicate the exercise in Tables 5 and 6 using the degree of efficiency of the judiciary as a different measure of institutional quality. This variable, built by La Porta et al. (2003), captures the legal costs of contract enforcement and takes values in $[0,7]$.

The evidence in columns 1 and 2 of Table 6 shows that contractual protection does not bring heterogeneity in the effects of financial liberalization and crises on growth, which remain respectively positive and negative.

\subsection{Liberalization, crises and financial development}

The evidence in the previous sections suggests that bank crises tend to restrain growth, but to a lesser extent if good institutions and financial openness help channelling funds into the economy. Moreover, column 4 in Table 2 indicates that capital account liberalization becomes uninfluential for growth, once we control for financial depth. These results suggest that the effect of capital account liberalization on growth is generally positive, and is possibly transmitted through the credit market. In this section, we assess how financial development $(F D)$ is affected by international liberalization and bank crises. To this end, we estimate the following dynamic system

$$
\begin{aligned}
\Delta F D_{i t} & =a \Delta F D_{i t-1}+b \Delta F l i b_{i t}+c \Delta B c r_{i t}+g \Delta \text { interaction }_{i t}+\Delta u_{t}+\Delta e_{i t} \\
F D_{i t} & =a\left(F D_{i t-1}\right)+b\left(\text { Flib }_{i t}\right)+c\left(\text { Bcr }_{i t}\right)+g\left(\text { interaction }_{i t}\right)+h_{i}+u_{t}+e_{i t}
\end{aligned}
$$

with two-step GMM. The coefficients in column 1 of Table 4 strongly support the hypothesis that capital account liberalization boosts financial depth ${ }^{19}$. The estimates in columns 2 and 4 show that financial liberalization has the same effects across countries with different institutional and economic development. Column 1 does not support the view that bank crises slow

\footnotetext{
${ }^{19}$ This result is consistent with previous evidence by Levine (2001) and Klein and Olivei (2000).
} 
down the process of financial development ${ }^{20}$. However, column 3 suggests that feedback from banking crises to credit market depth may indeed take place, with the expected positive and negative signs, respectively in countries with high and low degrees of property rights protection.

Columns 3 and 4 of Table 6 instead suggest that contractual protection plays a role in shaping the effect of openness and bank crises on financial depth. A good legal environment for business turns bank crises into expansions of the credit markets, consistent with the "bumpy path" proposed by Tornell et al. (2004). Vice-versa, where contractual rights are weak, credit markets are restrained by both openness and banking crises.

\section{Conclusion}

This paper provides an enpirical evaluation of the effects of financial liberalization and banking crises on growth. Our analysis accounts for the interaction between liberalization and crises, and allows for unequal effects across countries with different degrees of institutional and economic development. We also investigate the transmission of these effects through financial depth.

The overall lesson we draw from the results in section 3 is that the removal of capital account restrictions boosts growth mainly through indirect effects. In fact, financial liberalization has not only a beneficial impact on financial development but also allows to smooth the destructive effects of financial distress. Banking crises are indeed extremely harmful for economic performance. The cost of crises is higher in countries with bad institutions, as well as in the closed ones, while they have less impact in liberalized economies and in countries with higher quality of institutions. The effect of banking crises on growth is mainly a direct one, even though we show that feedbacks on credit market development are also possible.

The positive effects of financial liberalization are robust to different definition. In fact, we also show a positive relation between equity market liberalization and growth. Our results, consistent with Bekaert et al.(2004), point towards a direct effect of equity market integration. However, equity market openness and banking crises have strong opposite effects but do not interact. This evidence can be partly reconciled with the mechanism

\footnotetext{
${ }^{20}$ Demirguc-Kunt and Detragiache (1998) also show that financial liberalization tend to push financial development while financial fragility slows down the process.
} 
proposed by Tornell et al. (2004). In fact, firms that rely on credit may be severely hurt by banking crises, and find it difficult to shift abruptly to equity financing, even if they can sell shares on the international market. If instead they have free access to international credit markets, they might raise funds more easily there, and thus suffer less from domestic crises. 


\section{References}

[1] Acemoglu, Daron and Simon Johnson (2003) "Unbundling institutions", MIT Mimeo

[2] Acemoglu, Daron and Fabrizio Zilibotti (1997) "Was Prometeus Unbound by Chance? Risk, Diversification and Growth", Journal of Political Economy, 105, 709-752.

[3] Aizenmann, Joshua (2002) "Financial Opening: Evidence and Policy Options", NBEP, wp 8900.

[4] Arellano, Manuel and Stephen Bond (1991) "Some Test of Specification fo Panel Data: Monte-Carlo Evidence and Application to Employment Equations", Review of Economic Studies, 58(2), 277-297.

[5] Arellano, Manuel and Olivia Bover (1995) "Another Look at The Instrumental Variable Estimation of Errorr-Component Models", Journal of Econometrics, 68, 29-52.

[6] Arteta, Carlos, Barry Eichengreen and Charles Wyplosz (2001) "When Does Capital Account Liberalization Help More than Hurts?", Mimeo.

[7] Bacchetta, Philippe and Eric Van Wincoop (1998) "Capital Flow to Emerging Markets: Liberalization, Overshooting, and Volatility." NBER wp 6530.

[8] Barro, Robert J. (1991) "Economic Growth in a cross-section of countries", Quarterly Journal of Economics, 106 407-43.

[9] Barro, Robert J. (2001). "Determinants of Economic Growth: A CrossCountry Empirical Study", Harvard Institute for International Development, Development Discussion Paper No. 579.

[10] Barro, Robert J. (2001). "Economic Growth in East Asia Before and After the Financial Crisis." NBER wp 8330.

[11] Barro, Robert, N. Gregory Mankiw and Xavier Sala-i-Martin (1995) "Capital Mobility in Neoclassical Models of Growth." The American Economic Review 85(1) 103-115

[12] Barro, Robert and Xavier Sala-i-Martin (1995) Economic Growth. MIT Press. 
[13] Barth, James R., Gerard Jr Caprio and Ross Levine (2000) "Banking Systems Around the Globe: Do regulation and Ownership Affect Performance and Stability?", Mimeo.

[14] Barth, James R., Gerard Jr Caprio and Ross Levine (2000) "The Regulation and Supervision on Banks Around the World: a new Dataset.", Mimeo.

[15] Beck, Thorsten, Asli Demirgüç-Kunt and Ross Levine (2000) "A new database on financial development and structure", World Bank Economic Review, September 2000, 597-605.

[16] Beck, Thorsten, Ross Levine and Norman Loayza (1999) "Financial Intermediation and Growth: Causality and Causes." Mimeo.

[17] Beck, Thorsten, Ross Levine and Norman Loayza (2000) "Finance and the Sources of Growth." Journal of Financial Economics 58.

[18] Beck, Thorsten and Ross Levine (2001) "Stock Markets, Banks, and Growth: Correlation and Causality." Mimeo.

[19] Bekaert, Geert, Campbell R. Harvey and Christian Lundblad (2003) "Does Financial Liberalization Spur Growth?" NBER wp 8245.

[20] Berglof, Erik and Patrick Bolton (2000) "The Great Divide and BeyondFinancial Architecture in Transition." Mimeo.

[21] Blundell, Richard and Stephen Bond (1998) "Initial Conditions and Moment Restrictions in Dynamic Panel Data Models". Journal of Econometrics, 87, 115-143.

[22] Bond, Stephen, Clive Bowsher and Frank Windmeijer (2001) "Criterion-based inference for GMM in autoregressive panel data models", Economics Letters, 73, 379-388

[23] Caprio, Gerard and Daniela Klingebiel (2003) "Episodes of Systemic and Borderline Financial Crises", Mimeo

[24] Caselli, Francesco, Gerardo Esquivel and Fernando Lefort (1996) "Reopening the Convergence Debate: a New Look at Cross-Country Growth Empirics", Journal of Economic Growth, 1, 363-389. 
[25] Chanda, Areendam (2001) "The Influence of Capital Controls on Long Run Growth: Where and How Much?". Brown University, Mimeo .

[26] Cull, Robert, Lemma W. Senbet and Marco Sorge (2000) "Deposit Insurance and Financial Development." World Bank, Mimeo.

[27] De Gregorio, José and Jong-Wha Lee (2004) "Growth and Adjustment in East Asia and Latin America", ADB Institute Research Paper.

[28] Demirguc-Kunt, Asli and Erica Detragiache (1998) "The Determinants of Banking Crises in Developing and Developed Countries." IMF Staff Papers 45.

[29] Demirguc-Kunt, Asli and Erica Detragiache (2000) "Does Deposit Insurance Increase Banking System Stability?.” World Bank, Mimeo.

[30] Demirguc-Kunt, Asli and Ross Levine (1999) "Bank_Based and Market-Based Financial Systems: Cross-Country Comparisons." World Bank, Mimeo.

[31] Dornbusch, Rudiger and Alejandro Reynoso (1989) "Financial Factors in Economic Development." The American Economic Review, 79.

[32] Edison, Hali J., Michael W. Klein, Luca Ricci and Torsten Sloek (2002) "Capital account liberalization and economic performance: survey and synthesis", NBER Working Paper 9100.

[33] Edwards, Sebastian (1993) "Openness, Trade Liberalization, and Growth in Developing Countries." Journal of Economic Literature 31.

[34] Edwards, Sebastian (1999) "The Length and Cost of Banking Crises", IMF Working Paper 99/30.

[35] Edwards, Sebastian (2001) "Capital Mobility and Economic Performance: Are Emerging Economies Different?" NBER wp 8076.

[36] Eichengreen, Barry and David Leblang (2003) "Capital Account Liberalization and Growth: Was Mr. Mahathir Right?" International Journal of Finance and Economics, 8: 205-224.

[37] Eichengreen, Barry and Michael Mussa (1998) "Capital Account Liberalization and IMF". Financial and Development 35, IMF. 
[38] Eichengreen, Barry, Michael Mussa, Giovanni Dell'Ariccia, Erica Detragiache, Gian Maria Milesi_Ferretti and Andrew Tweedie (1999) "Liberalizing Capital Movements: Some Analytical Issues." IMF, Economic Issues 17.

[39] Eichengreen, Barry (2001) "Capital Account Liberalization: What Do the Cross-Country Studies Tell Us?" University of California, Berkeley, Mimeo.

[40] Greenwood, Jeremy and Boyan Jovanovic (1990) "Financial Development, Growth, and the Distribution Income." Journal of Political Economy, 98.

[41] Grilli, Vittorio and Gian Maria Milesi-Ferretti (1995) "Economic Effect and Structural Determinants of Capital Controls", IMF Staff Papers, Vol. 42, No. 3.

[42] Hall, R. and C. Jones (1999) "Why Do Some Countries Produce So Much More Output per Worke Than Others?", Quarterly Journal of Economics, 114, 83-116.

[43] Honohan, Patrick and Daniela Klingebiel, 2001 "Controlling Fiscal Costs of Banking Crises", World Bank Policy Research Working Paper 2441.

[44] Islam, Nazrul, 1995 "Growth Empirics: A Panel Data Approach". Quarterly Journal of Economics, 110, 1127-1170.

[45] Kaminsky, Graciela and Carmen Reinhart (1999) "The Twin Crises: Causes of Banking and Balance-of-Payments Problems", American Economic Review, 89(3) 473-500

[46] Kaminsky, Graciela and Sergio Schmukler, (2002) "Short-Run Pain, Long-Run Gain: The Effects of Financial Liberalization", Mimeo.

[47] King, Robert G. and Ross Levine (1993) "Finance and Growth: Schumpeter Might be Right." Quarterly Journal of Economics 108.

[48] Klein,Michael and Giovanni Olivei (1999) "Capital Account Liberalization, Financial Depth, and Economic Growth." NBER wp 7384.

[49] Kraay, Aart (1998) "In Search of the Macroeconomic Effects of Capital Account Liberalization" World Bank, Mimeo. 
[50] La Porta, Rafael, Florencio Lopez-de-Silanes, Andrei Shleifer and Robert W. Vishny (1997) "Law and finance", Journal of Political Economy 106, 1113-1155.

[51] La Porta, Rafael, Florencio F. Lopez-de-Silanes and Andrei Shleifer I (2003) "What Works in Securities Laws?" Harvard, Mimeo.

[52] Levine, Ross (1997) "Financial Development and Economic Growth: Views and Agenda." Journal of Economic Literature 35.

[53] Levine, Ross (2000). "International Financial Liberalization and Economic Growth." Review of International Economics

[54] Martin, Philippe and Helene Rey (2002). "Financial Globalization and Emerging Markets: With or Without Crash?," NBER Working Papers 9288 .

[55] McKinnon, Ronald I. (1988) "Monetary and Exchange Rate Policies for International Financial Stability: A Proposal". The Journal of Economic Perspectives, 2.

[56] Miniane, Jacques (2000) "A New Set of Measures on Capital Account Restrictions", Johns Hopkins University, Mimeo.

[57] Prasad, Eswar, Kenneth Rogoff, Shang-Jin Wei and M. Ayhan Kose (2003) "Effects of Financial Globalization on Developing Countries: some Empirical Evidence", IMF

[58] Quinn, Dennis (1997) "The Correlates of Change in International Financial Regulation", The American Political Science Review 91.

[59] Rodrik, Dani (1998) "Who Needs Capital-Account Convertibility?" Harvard University, Mimeo.

[60] Temple, Jonathan (1999) "The New Growth Evidence", Journal of Economic Literature 37, 112-156.

[61] Tornell, Aaron, Frank Westermann and Lorenza Martinez (2004) "The Positive Link Between Financial Liberalization Growth and Crises", NBER wp 10293

[62] Wyplosz, Charles (2002) "How Risky is Financial Liberalization in the Developing Countries?" Comparative Economic Studies, June, forthcoming 


\begin{tabular}{|c|c|c|c|c|c|c|c|c|c|c|c|}
\hline \multicolumn{12}{|c|}{ Table A Countries, Financial Liberalization and Growth } \\
\hline Country & \# opIMF & \# & $\# \mathrm{bc} 2$ & $\# \mathrm{bc1}$ & Growth & Country & \# opIMF & \# opBHL & $\# \mathrm{bc} 2$ & $\# \mathrm{bcl}$ & Growth \\
\hline Algeria & 0 & 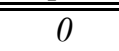 & 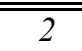 & 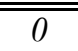 & 1.192 & Kenia & 0 & 1 & 9 & 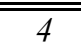 & 0.377 \\
\hline Argentina & 3 & 1 & 10 & 0 & 0.497 & Korea & 0 & 1 & 3 & 0 & 5.828 \\
\hline Australia & 12 & 0 & 0 & 4 & 2.021 & Lesotho & 0 & 0 & 0 & 12 & 1.545 \\
\hline Austria & 5 & 0 & 0 & 0 & 2.296 & Malawi & 0 & 0 & 0 & 0 & 1.237 \\
\hline Bangladesh & 0 & 1 & 10 & 0 & 2.174 & Malaysia & 21 & 1 & 3 & 4 & 4.020 \\
\hline Barbados & 0 & 0 & 0 & 0 & 2.664 & Mali & 0 & 0 & 3 & 0 & 0.539 \\
\hline Belgium & 21 & 0 & 0 & 0 & 2.039 & Mauritius & 0 & 1 & 0 & 1 & 4.257 \\
\hline Benin & 0 & 0 & 3 & 0 & 0.768 & Mexico & 7 & 1 & 15 & 0 & 0.887 \\
\hline Bolivia & 16 & 0 & 9 & 0 & -0.295 & Mozambique & 0 & 0 & 9 & 0 & -2.361 \\
\hline Botswana & 0 & 1 & 0 & 2 & 5.102 & Nepal & 0 & 0 & 1 & 0 & 1.959 \\
\hline Brasil & 0 & 1 & 7 & 0 & 1.200 & Netherlands & 19 & 0 & 0 & 0 & 1.960 \\
\hline Cameroon & 0 & 0 & 11 & 0 & 0.132 & NewZealand & 12 & 1 & 0 & 4 & 0.802 \\
\hline Canada & 21 & 0 & 3 & 0 & 1.844 & Nicaragua & 3 & 0 & 11 & 0 & -4.073 \\
\hline Central Africa & 0 & 0 & 24 & 0 & -2.805 & Niger & 1 & 0 & 17 & 0 & -1.321 \\
\hline Chile & 0 & 1 & 7 & 0 & 3.459 & Norway & 1 & 0 & 7 & 0 & 2.704 \\
\hline Colombia & 0 & 1 & 6 & 0 & 1.543 & Pakistan & 0 & 1 & 0 & 0 & 2.729 \\
\hline Congo & 0 & 0 & 8 & 0 & 1.531 & Panama & 21 & 0 & 2 & 0 & 1.435 \\
\hline Costa Rica & 3 & 0 & 1 & 6 & 0.805 & Papua NGuinea & 0 & 0 & 0 & 11 & -0.851 \\
\hline Cyprus & 0 & 0 & 0 & 0 & 5.968 & Paraguay & 2 & 0 & 5 & 0 & 1.673 \\
\hline Denmark & 8 & 0 & 0 & 6 & 1.838 & Peru & 9 & 1 & 8 & 0 & -0.697 \\
\hline Dominican Rep & 0 & 0 & 0 & 0 & 2.722 & Philippines & 0 & 1 & 9 & 0 & 0.736 \\
\hline Ecuador & 17 & 1 & 9 & 0 & -0.045 & Portugal & 3 & 1 & 0 & 0 & 3.042 \\
\hline Egypt & 0 & 1 & 5 & 5 & 3.661 & Rwanda & 0 & 0 & 0 & 9 & 0.084 \\
\hline
\end{tabular}




\begin{tabular}{|c|c|c|c|c|c|c|c|c|c|c|c|}
\hline \multicolumn{12}{|c|}{ Table A (cont'd). Countries, Financial Liberalization and Growth } \\
\hline Country & \# opIMF & \# \# opBHL & \# \#bc2 & \#bcl & Growth & Country & \# opIMF & \# opBHL & \# \#bc2 & \#bc1 & Growth \\
\hline El Salvador & 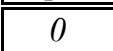 & 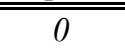 & 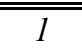 & 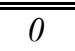 & -0.036 & Senegal & 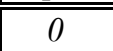 & 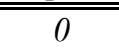 & 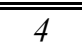 & 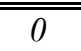 & 0.003 \\
\hline Fiji & 0 & 0 & 0 & 0 & 1.216 & Sierra Leone & 0 & 0 & 10 & 0 & -2.047 \\
\hline Finland & 5 & 0 & 4 & 0 & 2.007 & Singapore & 18 & 0 & 0 & 1 & 5.486 \\
\hline France & 6 & 0 & 0 & 2 & 1.843 & South Africa & 0 & 1 & 0 & 12 & -0.053 \\
\hline Gambia & 5 & 0 & 0 & 7 & -0.310 & Spain & 2 & 1 & 9 & 0 & 1.852 \\
\hline Germany & 21 & 0 & 0 & 3 & 2.095 & Sri Lanka & 0 & 1 & 5 & 0 & 2.677 \\
\hline Ghana & 0 & 1 & 8 & 3 & 0.212 & Sweden & 3 & 0 & 1 & 0 & 1.404 \\
\hline Greece & 0 & 1 & 0 & 5 & 1.253 & Switzerland & 4 & 0 & 0 & 0 & 0.968 \\
\hline Guatemala & 12 & 0 & 0 & 4 & 0.485 & Syria & 0 & 0 & 0 & 0 & 1.892 \\
\hline Haiti & 0 & 0 & 0 & 0 & 4.066 & Thailand & 0 & 1 & 8 & 0 & 4.765 \\
\hline Honduras & 8 & 0 & 0 & 0 & 0.098 & Togo & 0 & 0 & 3 & 0 & -0.967 \\
\hline Hong Kong & 21 & 0 & 0 & 6 & 4.622 & Trinidad \& Tobagc & 2 & 1 & 0 & 12 & 1.620 \\
\hline Iceland & 0 & 1 & 0 & 3 & 2.158 & Tunisia & 0 & 1 & 0 & 5 & 2.483 \\
\hline India & 0 & 1 & 0 & 7 & 3.298 & Turkey & 0 & 1 & 4 & 1 & 1.688 \\
\hline Indonesia & 21 & 1 & 3 & 0 & 3.801 & Uganda & 0 & 0 & 6 & 0 & 1.719 \\
\hline Iran & 3 & 0 & 0 & 0 & 0.504 & United Kingdom & 17 & 0 & 0 & 22 & 2.073 \\
\hline Ireland & 4 & 0 & 0 & 0 & 4.324 & United States & 21 & 0 & 0 & 8 & 2.404 \\
\hline Israel & 0 & 1 & 7 & 0 & 1.676 & Uruguay & 15 & 0 & 4 & 0 & 1.723 \\
\hline Italy & 6 & 0 & 0 & 6 & 2.273 & Venezuela & 9 & 1 & 2 & 5 & -1.046 \\
\hline Jamaica & 0 & 1 & 6 & 0 & -0.268 & Zaire & 0 & 0 & 0 & 0 & -5.585 \\
\hline Japan & 16 & 1 & 9 & 0 & 2.528 & Zambia & 0 & 0 & 1 & 0 & -1.818 \\
\hline Jordan & 0 & 1 & 0 & 2 & 2.141 & Zimbabwe & 0 & 1 & 5 & 0 & 0.200 \\
\hline
\end{tabular}




\begin{tabular}{|c|c|c|c|}
\hline Variable & Definition & Availability & Sources \\
\hline $\bar{y}$ & " Beginning of period real per capita GDP & yearly, 1975-99 & " Penn World Tables 6.1 \\
\hline $\sec 25$ & $\begin{array}{l}\text { Percentage of population aged } 25 \text { or above } \\
\text { with some secondary education }\end{array}$ & 5-year, 1975-99 & Barro and Lee (2001) \\
\hline grpop & average yearly population growth rate & yearly, 1975-99 & Penn World Tables 6.1 \\
\hline gov & government share of $y$ & yearly, 1975-99 & Penn World Tables 6.1 \\
\hline$i n v$ & investment share of $y$ & yearly, 1975-99 & Penn World Tables 6.1 \\
\hline privo & $\begin{array}{l}\text { Private credit by deposit money banks } \\
\text { and other financial institutions to GDP }\end{array}$ & yearly, 1975-99 & Beck et al. (2003) \\
\hline$o p I M F$ & $\begin{array}{l}\text { Equals } 0 \text { if restrictions on capital account transactions } \\
\text { are in place, } 1 \text { otherwise. } n \text {-year period average }\end{array}$ & yearly, 1975-99 & AREAER, IMF \\
\hline$o p B H L$ & $\begin{array}{l}\text { Equals } 1 \text { ever since the year of official equity market } \\
\text { liberalization, } 0 \text { elsewhere. } n \text {-year period average }\end{array}$ & yearly, 1980-99 & Bekaert et al. (2003) \\
\hline$B c r$ & $\begin{array}{l}\text { Equals } 2 \text { if systemic banking crises, } 1 \text { if non-systemic } \\
\text { crises, } 0 \text { if no crises have occurred in the year. }\end{array}$ & yearly, 1975-99 & $\begin{array}{l}\text { Caprio and Klingebiel } \\
(2003)\end{array}$ \\
\hline Bcr012 & $\begin{array}{l}\text { Equals } 2 \text { if systemic banking crises, } 1 \text { if non-systemic } \\
\text { crises, } 0 \text { if no crises have occurred in the period }\end{array}$ & & CK (2003) \\
\hline Bcr012av & Average of Bcr over the period & & CK (2003) \\
\hline$G A D P$ & $\begin{array}{l}\text { Government anti-diversion policy index. Accounts for: law } \\
\text { and order, burocratic quality, risk of expropriation, corruption, } \\
\text { government repudiation of contracts. Values in }[0,1]\end{array}$ & average $1986-95$ & $\begin{array}{l}\text { Hall and Jones } \\
(1999)\end{array}$ \\
\hline$L D C$ & Dummy for developing countries & & WDI \\
\hline$e f f \_j u d$ & $\begin{array}{l}\text { Assessment of the efficiency and integrity of the legal } \\
\text { environment as it affects business, particularly foreign } \\
\text { firms. Values in }[0,10]\end{array}$ & average $1980-83$ & $\begin{array}{l}\text { La Porta et al } \\
(2003), \text { from ICR }\end{array}$ \\
\hline
\end{tabular}




\begin{tabular}{|c|c|c|c|c|c|}
\hline & $\begin{array}{l}\text { Open vs } \\
\text { Closed CA }\end{array}$ & $\begin{array}{l}\text { Open vs } \\
\text { Closed SM }\end{array}$ & $\begin{array}{l}\text { BC vs } \\
\text { No BC }\end{array}$ & $\begin{array}{l}\text { Systemic BC } \\
\text { vs No BC }\end{array}$ & $\begin{array}{l}\text { Non-systemic } \\
\text { BC vs No BC }\end{array}$ \\
\hline Growth & $\begin{array}{l}.008^{* * *} \\
(.002)\end{array}$ & $\begin{array}{l}.016^{* * *} \\
(.002)\end{array}$ & $\begin{array}{l}-.019^{* * *} \\
(.003)\end{array}$ & $\begin{array}{l}-.023^{* * *} \\
(.003)\end{array}$ & $\begin{array}{l}-.05 \\
(.005)\end{array}$ \\
\hline Financial Development & $\begin{array}{l}.034^{* * *} \\
(.009)\end{array}$ & $\begin{array}{l}.039^{* * *} \\
(.007)\end{array}$ & $\begin{array}{c}-.039^{* * *} \\
(.011)\end{array}$ & $\begin{array}{c}-.057^{* * *} \\
(.017)\end{array}$ & $\begin{array}{c}-.001 \\
(.011)\end{array}$ \\
\hline Bank Crises & $\begin{array}{l}.009 \\
(.025)\end{array}$ & $\frac{-.057^{* *}}{(.025)}$ & & & \\
\hline Systemic BC & $\frac{-.098^{* * *}}{(.018)}$ & ${ }^{-.099^{* * *}}$ & & & \\
\hline Non-Systemic BC & $l_{(.021)}^{.107^{* * *}}$ & $\begin{array}{l}.043^{* * *} \\
(.017)\end{array}$ & & & \\
\hline Period & $1975-99$ & $1980-99$ & $1975-99$ & $1975-99$ & $1975-99$ \\
\hline \multicolumn{6}{|c|}{$\begin{array}{l}\text { This table reports the differences in mean between treated (open, bank crisis) and control (closed, no bank crisis) } \\
\text { groups, and their standard errors (in parenthesis). }{ }^{* *} \text { and }{ }^{* *} \text { indicate rejection of the null of zero-difference at } 1 \\
\text { and } 5 \% \text { significance level. The test is performed on annual data for the countries in Table A. The variables of } \\
\text { interest are the growth rate of real per capita GDP, the growth rate of credit to the private sector, and the } 0-1 \\
\text { indicators of occurrence of bank crises. }\end{array}$} \\
\hline
\end{tabular}




\begin{tabular}{|c|c|c|c|c|c|c|c|c|}
\hline \multicolumn{9}{|c|}{$\begin{array}{c}\text { Table 2. Financial Liberalization, Bank Crises and Growth } \\
\text { Dynamic Panel Data - System GMM }\end{array}$} \\
\hline & GMM & GMM & GMM & GMM & GMM & GMM & GMM & GMM \\
\hline $\bar{~} y_{t-5}$ & $\begin{array}{l}\mathbf{9 5 4} \\
(.036)\end{array}$ & $\begin{array}{l}\mathbf{9 2 9} \\
(.034)\end{array}$ & $\begin{array}{l}\mathbf{9 3 3} \\
(.033)\end{array}$ & $\begin{array}{l}\mathbf{9 0 6} \\
(.034)\end{array}$ & $\begin{array}{l}\mathbf{9 7 2} \\
(.035)\end{array}$ & $\begin{array}{l}\mathbf{9 4 6} \\
.032)\end{array}$ & $\begin{array}{l}\mathbf{9 4 6} \\
(.032)\end{array}$ & $\begin{array}{l}\mathbf{9 2 3} \\
(.037)\end{array}$ \\
\hline $\sec 25$ & $\begin{array}{l}-.044 \\
(.025)\end{array}$ & $\begin{array}{l}-.016 \\
(.028)\end{array}$ & $\begin{array}{l}-.021 \\
(.028)\end{array}$ & $\begin{array}{l}-.015 \\
(.027)\end{array}$ & $\begin{array}{l}-.045 \\
(.032)\end{array}$ & $\begin{array}{l}-.004 \\
(.029)\end{array}$ & $\begin{array}{l}-.003 \\
(.029)\end{array}$ & $\begin{array}{l}-.002 \\
(.029)\end{array}$ \\
\hline grpop & $\begin{array}{l}.317 \\
.2 .311)\end{array}$ & $\begin{array}{c}-1.284 \\
(2.178)\end{array}$ & $\begin{array}{c}-1.401 \\
(2.101)\end{array}$ & $\begin{array}{l}-.998 \\
(2.014)\end{array}$ & $\begin{array}{l}1.563 \\
(2.464)\end{array}$ & $\begin{array}{l}1.156 \\
(2.168)\end{array}$ & $\begin{array}{l}1.142 \\
(2.08)\end{array}$ & $\begin{array}{l}1.136 \\
(2.201)\end{array}$ \\
\hline gov & $\begin{array}{l}-.002 \\
(.002)\end{array}$ & $\begin{array}{l}.001 \\
(.002)\end{array}$ & $\begin{array}{l}.001 \\
(.002)\end{array}$ & $\begin{array}{l}.001 \\
(.002)\end{array}$ & $\begin{array}{l}-.001 \\
(.002)\end{array}$ & $\begin{array}{l}.002 \\
(.002)\end{array}$ & $\begin{array}{l}.002 \\
(.002)\end{array}$ & $\begin{array}{l}.002 \\
(.002)\end{array}$ \\
\hline$i n v$ & $\begin{array}{l}.015 \\
(.002)\end{array}$ & $\begin{array}{l}.014 \\
(.002)\end{array}$ & $\begin{array}{l}.014 \\
(.002)\end{array}$ & $\begin{array}{l}.013 \\
(.002)\end{array}$ & $\begin{array}{l}.015 \\
. .002)\end{array}$ & $\begin{array}{l}.013 \\
(.002)\end{array}$ & $\begin{array}{l}.014 \\
(.002)\end{array}$ & $\begin{array}{l}.013 \\
(.002)\end{array}$ \\
\hline privo & & & & $\begin{array}{l}.086 \\
(.050)\end{array}$ & & & & $\begin{array}{l}.052 \\
(.057)\end{array}$ \\
\hline opIMF & $\begin{array}{l}.037 \\
(.046)\end{array}$ & $\begin{array}{l}.087 \\
(.041)\end{array}$ & $\begin{array}{l}.027 \\
(.044)\end{array}$ & $\begin{array}{l}.055 \\
(.040)\end{array}$ & & & & \\
\hline opBHL & & & & & $\begin{array}{l}.012 \\
.006)\end{array}$ & $\begin{array}{l}.013 \\
(.006)\end{array}$ & $\begin{array}{l}.011 \\
(.007)\end{array}$ & $\begin{array}{l}.012 \\
(.006)\end{array}$ \\
\hline Bcr012 & & $\begin{array}{c}-.041 \\
(.018)\end{array}$ & $\begin{array}{c}-.044 \\
(.017)\end{array}$ & $\begin{array}{l}-.043 \\
(.016)\end{array}$ & & $\begin{array}{c}-.051 \\
(.016)\end{array}$ & $\begin{array}{c}-.054 \\
(.019)\end{array}$ & $\begin{array}{c}-.053 \\
(.015)\end{array}$ \\
\hline opIMF * Bcr012 & & & $\begin{array}{l}.064 \\
(.039)\end{array}$ & & & & & \\
\hline opBHL * Bcr012 & & & & & & & $\begin{array}{l}.002 \\
(.006)\end{array}$ & \\
\hline Countries & 90 & 89 & 89 & 89 & 82 & 81 & 81 & 81 \\
\hline Period & 1975-99 & $1975-99$ & 1975-99 & 1975-99 & $1980-99$ & 1980-99 & 1980-99 & 1980-99 \\
\hline$m_{2}$ & .246 & .119 & .105 & .100 & .264 & .201 & .200 & .197 \\
\hline Sargan & .418 & .635 & .677 & .713 & .160 & .381 & .541 & .660 \\
\hline $\begin{array}{l}\text { System-GMM estin } \\
\text { log-differences of: } \\
\text { indicators of financ } \\
\text { for levels. Two-ster } \\
5 \text { and } 10 \text { per cent } \\
\text { test for second-ord }\end{array}$ & $\begin{array}{l}\text { es. De } \\
\text { ed rea } \\
\text { liberal } \\
\text { stimat } \\
\text { ificanc }\end{array}$ & $\begin{array}{l}\text { ent var } \\
\text { capita } \\
\text { ond and } \\
\text { Coeffi }\end{array}$ & $\begin{array}{l}\text { es: } \log \\
\mathrm{P}, \text { seco } \\
\text { s crises } \\
\text { s and }\end{array}$ & $\begin{array}{l}\text { log-dif } \\
\text { y attai } \\
\text { strume }\end{array}$ & $\begin{array}{l}\text { ce of } \mathrm{r} \\
\text { nt, gov }\end{array}$ & er capi & $\begin{array}{l}\text { DP. R } \\
\text { vestme } \\
\text { ences, }\end{array}$ & $\begin{array}{l}\text { essors are log an } \\
\text { share of GDP, } \\
\text { sed differences } \\
\text { st step. } \\
\text { test and } m_{2}\end{array}$ \\
\hline
\end{tabular}




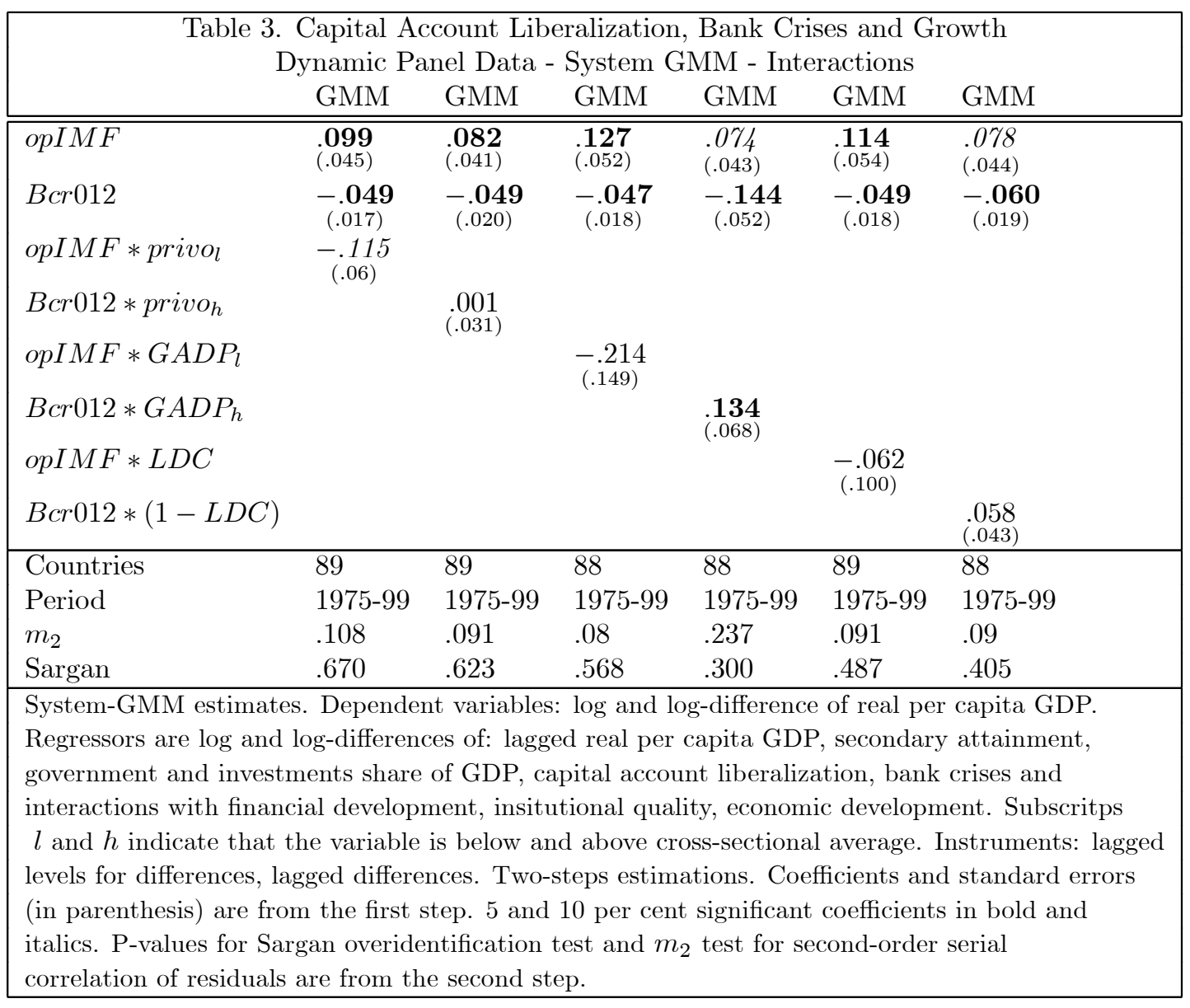




\begin{tabular}{|c|c|c|c|c|c|c|}
\hline \multicolumn{7}{|c|}{$\begin{array}{c}\text { Table 3b. Equity Market Liberalization, Bank Crises and Growth } \\
\text { Dynamic Panel Data - System GMM - Interactions }\end{array}$} \\
\hline & GMM & GMM & GMM & GMM & GMM & GMM \\
\hline$o p B H L$ & $\begin{array}{l}\mathbf{0 1 2} \\
(.006)\end{array}$ & $\begin{array}{l}\mathbf{0 1 0} \\
(.005)\end{array}$ & $\begin{array}{l}-.005 \\
(.009)\end{array}$ & $\begin{array}{l}.008 \\
(.006)\end{array}$ & $\begin{array}{l}.006 \\
(.011)\end{array}$ & $\begin{array}{l}\mathbf{0 1 0} \\
(.005)\end{array}$ \\
\hline Bcr 012 & $\begin{array}{l}-.048 \\
(.015)\end{array}$ & $\begin{array}{l}-.067 \\
(.020)\end{array}$ & $\begin{array}{l}-.056 \\
(.016)\end{array}$ & $\begin{array}{l}-.195 \\
(.052)\end{array}$ & $\begin{array}{l}-.053 \\
(.016)\end{array}$ & $\begin{array}{l}-.063 \\
(.015)\end{array}$ \\
\hline opBHL $*$ privo $_{l}$ & $\begin{array}{l}-.006 \\
(.007)\end{array}$ & & & & & \\
\hline Bcr $012 *$ privo $_{h}$ & & $\begin{array}{l}.042 \\
(.026)\end{array}$ & & & & \\
\hline$o p B H L * G A D P_{l}$ & & & $\begin{array}{l}.057 \\
(.037)\end{array}$ & & & \\
\hline$B c r 012 * G A D P_{h}$ & & & & $\begin{array}{l}.148 \\
(.064)\end{array}$ & & \\
\hline opBHL *LDC & & & & & $\begin{array}{l}.005 \\
(.012)\end{array}$ & \\
\hline$B c r 012 *(1-L D C)$ & & & & & & $\begin{array}{l}.056 \\
(.035)\end{array}$ \\
\hline Countries & 81 & 81 & 80 & 80 & 81 & 81 \\
\hline Period & 1980-99 & 1980-99 & 1980-99 & 1980-99 & 1980-99 & 1980-99 \\
\hline$m_{2}$ & .151 & .208 & .218 & .527 & .194 & .218 \\
\hline Sargan & .486 & .458 & .245 & .342 & .285 & .306 \\
\hline $\begin{array}{l}\text { System-GMM estimat } \\
\text { Regressors are log and } \\
\text { government and invest } \\
\text { interactions with finan } \\
l \text { and } h \text { indicate that } \\
\text { levels for differences, l} \\
\text { (in parenthesis) are fro } \\
\text { italics. P-values for Sa } \\
\text { correlation of residual }\end{array}$ & $\begin{array}{l}\text { Depende } \\
\text { og-differen } \\
\text { ents share } \\
\text { al develop } \\
\text { he variable } \\
\text { ged differ } \\
\text { the first } \\
\text { gan overid } \\
\text { are from tl }\end{array}$ & $\begin{array}{l}\text { t variables } \\
\text { es of: lagg } \\
\text { of GDP, ce } \\
\text { ent, insit } \\
\text { s below al } \\
\text { ces. Two- } \\
\text { ep. } 5 \text { and } \\
\text { tification } \\
\text { second st }\end{array}$ & $\begin{array}{l}\text { log and } l \\
d \text { real per } \\
\text { pital accou } \\
\text { tional qua } \\
d \text { above cr } \\
\text { teps estim } \\
10 \text { per cen } \\
\text { est and } m\end{array}$ & $\begin{array}{l}\text { g-differenc } \\
\text { apita GD } \\
\text { tt liberaliz } \\
\text { ty, econom } \\
\text { ss-section } \\
\text { tions. Co } \\
\text { significan } \\
\text { test for s }\end{array}$ & $\begin{array}{l}\text { of real pe } \\
\text { secondar } \\
\text { tion, bank } \\
\text { c developr } \\
\text { average. } \\
\text { ficients an } \\
\text { coefficient } \\
\text { cond-order }\end{array}$ & $\begin{array}{l}\text { capita GDP. } \\
\text { attainment, } \\
\text { crises and } \\
\text { ent. Subscritps } \\
\text { istruments: lagged } \\
\text { standard errors } \\
\text { in bold and } \\
\text { serial }\end{array}$ \\
\hline
\end{tabular}




\begin{tabular}{|c|c|c|c|c|c|}
\hline $\begin{array}{r}\text { Table 4. Capital } \\
\text { Financial Developr }\end{array}$ & $\begin{array}{r}\text { Accoun } \\
\text { nent - D } \\
\text { GMM }\end{array}$ & $\begin{array}{c}\text { Liberali } \\
\text { namic P } \\
\text { GMM }\end{array}$ & $\begin{array}{c}\text { zation, I } \\
\text { anel Dat } \\
\text { GMM }\end{array}$ & $\begin{array}{c}\text { ank Cri } \\
\text { a - Syst } \\
\text { GMM }\end{array}$ & $\begin{array}{l}\text { es and } \\
\text { GMM } \\
\text { GMM }\end{array}$ \\
\hline privot-1 $_{t-1}$ & $\begin{array}{l}\mathbf{7 2 5} \\
(.078)\end{array}$ & $\begin{array}{l}\mathbf{7 0 9} \\
(.078)\end{array}$ & $\begin{array}{l}.731 \\
.080)\end{array}$ & $\begin{array}{l}\mathbf{7 1 9} \\
(.086)\end{array}$ & $\begin{array}{l}\mathbf{7 3 4} \\
(.077)\end{array}$ \\
\hline$o p I M F$ & $\begin{array}{l}.516 \\
(.134)\end{array}$ & $\begin{array}{l}.654 \\
(.199)\end{array}$ & $\begin{array}{l}.469 \\
.158)\end{array}$ & $\begin{array}{l}.584 \\
. .217)\end{array}$ & $\begin{array}{l}.399 \\
(.154)\end{array}$ \\
\hline Bcr 012 & $\begin{array}{l}.02 \\
(.063)\end{array}$ & $\begin{array}{l}.025 \\
.063)\end{array}$ & $\begin{array}{l}-.390 \\
(.224)\end{array}$ & $\begin{array}{l}.021 \\
.063)\end{array}$ & $\begin{array}{l}-.073 \\
(.069)\end{array}$ \\
\hline$o p I M F * G A D P_{l}$ & & $\begin{array}{l}-.618 \\
(.439)\end{array}$ & & & \\
\hline$B c r 012 * G A D P_{h}$ & & & $\begin{array}{l}.602 \\
(.313)\end{array}$ & & \\
\hline$o p I M F * L D C$ & & & & $\begin{array}{l}-.165 \\
(.342)\end{array}$ & \\
\hline$B c r 012 *(1-L D C)$ & & & & & $\begin{array}{l}.528 \\
. .249)\end{array}$ \\
\hline Countries & 79 & 78 & 78 & 79 & 79 \\
\hline Period & $75-99$ & $75-99$ & 75-99 & $75-99$ & $75-99$ \\
\hline$m_{2}$ & .216 & .275 & .384 & .276 & .185 \\
\hline Sargan & .394 & .501 & .451 & .432 & .411 \\
\hline \multicolumn{6}{|c|}{$\begin{array}{l}\text { System-GMM estimates. Dependent variables: log and log-difference of } \\
\text { private credit to GDP. Regressors are log and log-differences of: lagged } \\
\text { private credit to GDP, capital account liberalization, bank crises and } \\
\text { interactions with financial development, insitutional quality, economic } \\
\text { development. Subscritps } l \text { and } h \text { indicate that the variable is below and } \\
\text { above cross-section average. Instruments: lagged levels for differences, } \\
\text { lagged differences for levels. Two-steps estimations. Coefficients and } \\
\text { standard errors (in parenthesis) are from the first step. } 5 \text { and } 10 \text { per cent } \\
\text { significant coefficients in bold and italics. P-values for Sargan test and } \\
m_{2} \text { test for second-order serial correlation of residuals from the second. }\end{array}$} \\
\hline
\end{tabular}




\begin{tabular}{|c|c|c|c|c|c|c|}
\hline & \multicolumn{6}{|c|}{ Table 5. Financial Liberalization, Bank Crises and Growth } \\
\hline & opIMF & $B c r 012 a v$ & $\begin{array}{l}o p I M F * \\
B c r 012 a v\end{array}$ & opBHL & Bcr012av & $\begin{array}{l}\text { opBHL* } \\
\text { Bcr012av }\end{array}$ \\
\hline sys - GMM & $\begin{array}{l}.084 \\
(.039)\end{array}$ & $\begin{array}{l}-.037 \\
(.024)\end{array}$ & & ) & $\begin{array}{l}-.049 \\
(.022)\end{array}$ & \\
\hline sys $-G M M$ & $\begin{array}{l}.022 \\
(.043)\end{array}$ & $\begin{array}{l}-.048 \\
(.025)\end{array}$ & $\begin{array}{l}.133 \\
(.072)\end{array}$ & $\begin{array}{l}.014 \\
(.0086)\end{array}$ & $\begin{array}{l}-.046 \\
(.007)\end{array}$ & $\begin{array}{l}-.002 \\
(.009)\end{array}$ \\
\hline $\begin{array}{l}\text { OLS rows repl } \\
\text { rows Table } 2 \\
\text { (columns } 2-3, \\
\text { parenthesis, } 5\end{array}$ & $\begin{array}{l}\text { ate Table } \\
\text { lumns } 2- \\
7 \text { ), sys-G } \\
\text { and } 10 \%\end{array}$ & $\begin{array}{l}\text { columns 2- } \\
\text { 3-7), GLS T } \\
\text { I Table } 4 \text { ( } \\
\text { ificant coef }\end{array}$ & $\begin{array}{l}\text { 6-7) with } \\
\text { ble } 2 \text { b (colu } \\
\text { lunms } 2-3 \text {, } \\
\text { cients respe }\end{array}$ & $\begin{array}{l}\text { cr012av i } \\
\text { ns 2-3, 6- } \\
\text { 7). Stand } \\
\text { ively in br }\end{array}$ & $\begin{array}{l}\text { tead of } B c r \\
\text { diff-GMM } \\
d \text { errors wit } \\
d \text { and italics }\end{array}$ & $\begin{array}{l}12, \mathrm{FE} \\
\text { able } 3 \\
\mathrm{n}\end{array}$ \\
\hline
\end{tabular}




\begin{tabular}{|c|c|c|c|c|}
\hline $\begin{array}{r}\text { Table 6. Capital } \\
\text { Financi }\end{array}$ & evelopn & ent and $\mathrm{G}$ & rowth & \\
\hline & Growth & Growth & $\mathrm{FD}$ & FD \\
\hline$o p I M F$ & $\begin{array}{l}.025 \\
(.040)\end{array}$ & $\begin{array}{l}\mathbf{0 6 1} \\
(.027)\end{array}$ & $\begin{array}{l}.873 \\
(.118)\end{array}$ & $\begin{array}{l}.444 \\
(.118)\end{array}$ \\
\hline Bcr012 & $\begin{array}{c}-.034 \\
(.013)\end{array}$ & $\begin{array}{l}-.040 \\
(.026)\end{array}$ & $\begin{array}{l}.109 \\
(.093)\end{array}$ & $\begin{array}{l}-.126 \\
(.125)\end{array}$ \\
\hline$o p I M F * e f f \_j u d_{l}$ & $\begin{array}{l}.093 \\
. .083)\end{array}$ & & $\underset{(.448)}{-1.001}$ & \\
\hline Bcr012*eff_jud $d_{h}$ & & $\begin{array}{l}.019 \\
.043) \\
\end{array}$ & & $\begin{array}{l}.500 \\
(.184)\end{array}$ \\
\hline $\begin{array}{l}\text { Estimates i } \\
\text { eff_jud i } \\
\text { of Table } 6 . \\
\text { significant }\end{array}$ & $\begin{array}{l}\text { eplic } \\
D P \text {; }\end{array}$ & $\begin{array}{l}\text { columns } \\
\text { imn 3-4 } \\
\text { enthesis, } \\
\text { in bold }\end{array}$ & $\begin{array}{l}\text { of Tabl } \\
\text { cate co }\end{array}$ & $\begin{array}{l}\text { with } \\
\text { ans } 2-3 \\
\text { cent }\end{array}$ \\
\hline
\end{tabular}

